\title{
18. LITHOSTRATIGRAPHIC SUMMARY FOR LEG 175: ANGOLA-BENGUELA UPWELLING SYSTEM ${ }^{1}$
}

\author{
P.K. Pufahl, ${ }^{2}$ M.A. Maslin, ${ }^{3}$ L. Anderson,,${ }^{4}$ V. Brüchert,${ }^{5}$ F. Jansen,${ }^{6}$ H. Lin, ${ }^{7}$ M. Perez,${ }^{8}$ L. Vidal ${ }^{9}$, and \\ Shipboard Scientific Party ${ }^{10}$
}

\begin{abstract}
During Ocean Drilling Program Leg 175, 40 holes were drilled at 13 sites, and 8003 m were recovered with the aim of reconstructing the late Neogene history of the Angola-Benguela upwelling system on the southwest African margin. This system is one of the great upwelling regions of the world and is characterized by organic-rich sediments that provide an excellent record of productivity back to the middle Miocene. Understanding the sedimentology and stratigraphy of these sediments will provide important new information on the paleoceanography of this region, including the complex role the ocean plays in global carbon cycling and climate change.

This contribution summarizes the sedimentologic and stratigraphic data compiled on board the JOIDES Resolution between 12 August and 10 October 1997. The 13 drill sites can be divided into four regions based on sediment type and composition: (1) the Lower Congo Basin, (2) the Angola Basin, (3) the Walvis Ridge and Basin, and (4) the Cape Basin. The stratigraphy of each region is distinct and records the competing influences of current regime, shelf topography, and proximity to major river systems (both ancient and modern) and upwelling centers. The Lower Congo Basin is a hemipelagic environment containing finegrained sediments derived from the Congo River. Sedimentation within the Angola Basin is dominated by rain-out of hemipelagic silts and clays derived from coastal erosion and from the Kunene River to the south. Sediments within the Walvis Ridge and Basin consist of carbonate oozes and organic-rich clays, which record a strong upwelling signal from the Benguela Current. Deposition in the Cape Basin is dominated by pelagic settling of biogenic debris at the most southern tip of the Benguela Current upwelling center.
\end{abstract}

\section{INTRODUCTION}

During the Ocean Drilling Program (ODP) Leg 175, 40 holes were drilled at 13 sites along the southwest African margin between $5^{\circ}$ and $32^{\circ} \mathrm{S}$ (Fig. 1). Its primary aim is to reconstruct the Neogene paleocirculation patterns and upwelling history of the Angola-Benguela system. Four distinct regions along the west African coast can be identified based on modern sediment type and composition: (1) the Lower Congo Basin, where clays are predominant; (2) the Angola Basin, which mainly contains silty clays; (3) the Walvis Ridge and Basin, which collect both clays and carbonate oozes; and (4) the Cape Basin, which mainly contains carbonate oozes. The distinctive stratigraphy of each region is attributable to the competing influences of current regime, the proximity to major river systems (both modern and ancient), the proximity to the coast, the water depth, and the relative position to major upwelling centers. The purpose of this paper

${ }^{1}$ Wefer, G., Berger, W.H., Richter, C., et al., 1998. Proc. ODP, Init. Repts., 175: College Station, TX (Ocean Drilling Program).

${ }^{2}$ Department of Earth and Ocean Sciences, University of British Columbia, 6339 Stores Road, Vancouver V6T 124, British Columbia, Canada. ppufahl@eos.ubc.ca

${ }^{3}$ Environmental Change Research Center, University College of London, 26 Bedford Way, London WC1H 0AP, United Kingdom.

${ }^{4}$ Institute of Marine Sciences, University of California at Santa Cruz, Santa Cruz, CA 95064, U.S.A.

${ }^{5}$ Max Planck Institute for Marine Microbiology, Department of Biogeochemistry, Celsiusstrasse 1, D-28359 Bremen, Federal Republic of Germany.

${ }^{6}$ Netherlands Institute for Sea Research, P.O. Box 59, 1790 AB Texel, The Netherlands.

${ }^{7}$ Institute of Marine Geology and Chemistry, National Sun Yat-Sen University, Kaohsiung 804, Taiwan.

${ }^{8}$ Geosciences Research Division, Scripps Institution of Oceanography, University of California at San Diego, 9500 Gilman Drive, La Jolla, CA 92093-0215, U.S.A.

${ }^{9}$ Department of Earth Sciences, University of Bremen, Postfach 330440, 28334 Bremen, Federal Republic of Germany.

${ }^{10}$ Shipboard Scientific Party is given in the list preceding the Table of Contents. is to summarize and provide initial sedimentological interpretations of the stratigraphy of each of these regions.

\section{REGIONAL SETTING}

Sites 1075, 1076, and 1077 were drilled in the Lower Congo Basin to sample a complex depositional system dominated by riverine input, seasonal coastal upwelling, and excursions from the South Equatorial Countercurrent (see "Introduction" chapter, this volume). Sites 1078, 1079, and 1080 were drilled off Angola near $12^{\circ} \mathrm{S}$ to provide information on normal hemipelagic sedimentation, which is influenced neither by riverine input nor any sustained year-round upwelling. Sites 1081, 1082, 1083, and 1084, together with Deep Sea Drilling Project (DSDP) Sites 532 and 362 (Legs 75 and 40), were drilled to form a transect that is central to reconstructing the upwelling history of the Benguela Current. The transect begins in the north, on the Walvis Ridge, and extends to the south, within the Walvis Basin, where organic-rich sediments associated with intense upwelling dominate. Sites 1085, 1086, and 1087 were drilled to explore the early history of the Benguela Current and to detect the possible influence of the Agulhas Current. The sites are located close to the continent to detect upwelling and continental climatic signals.

\section{METHODOLOGY}

Complete stratigraphies were recovered by triple coring each site at a lateral offset of $\sim 10 \mathrm{~m}$. Sediments were advanced hydraulic piston cored (APC) to refusal, below which extended core barrel (XCB) coring was used in some holes to recover more compacted sediments to a maximum depth of 600 meters below seafloor (mbsf).

Sediments were classified based on their composition and texture (see "Lithostratigraphy" section, "Explanatory Notes" chapter, this volume). The principal name of the sediment is determined by the component or group of components (e.g., total biogenic carbonate) 


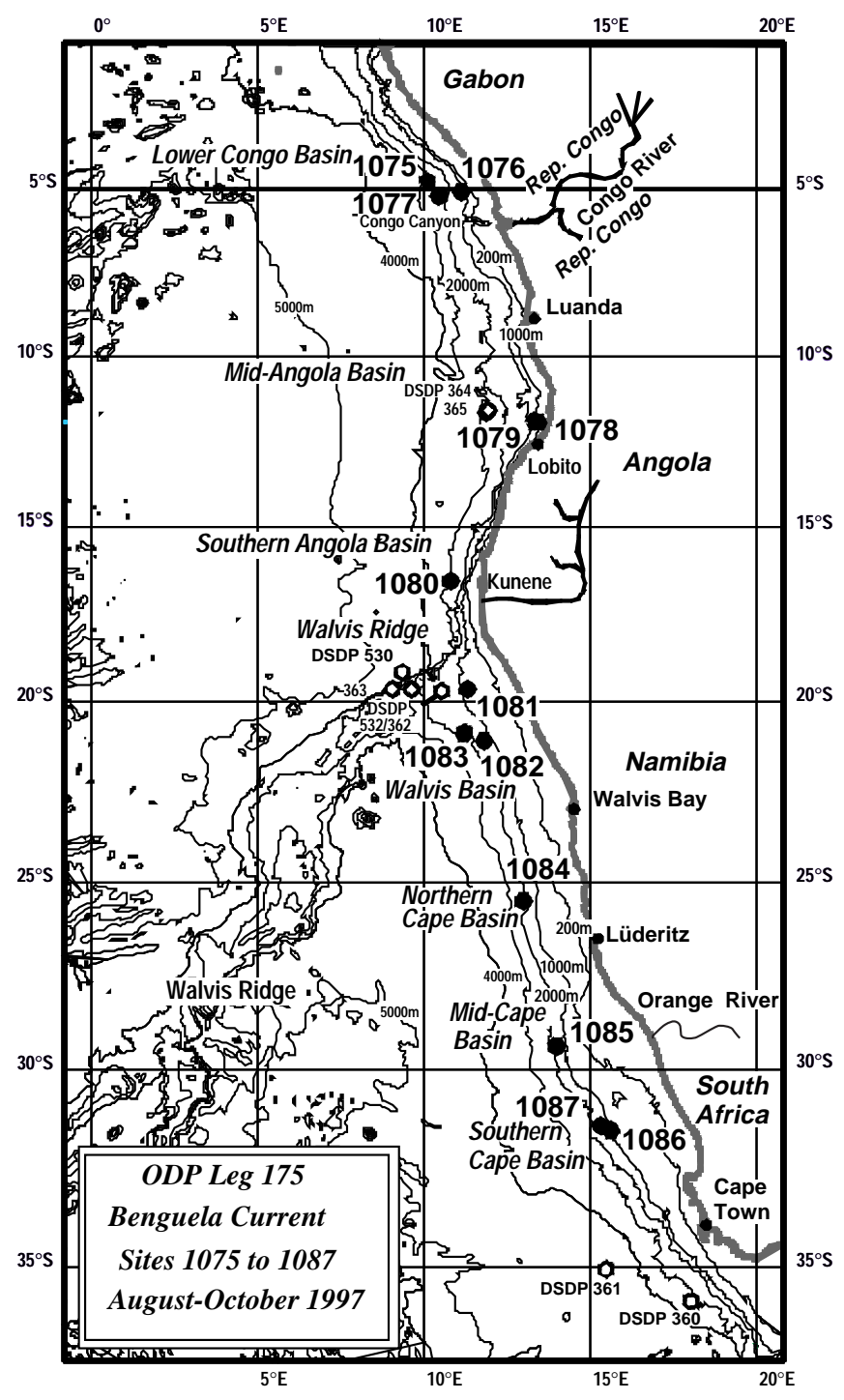

Figure 1. Location map of drilling sites on the southwest African margin occupied during ODP Leg 175.

that comprise(s) at least $60 \%$ of the sediment-except for equal proportions of biogenic and nonbiogenic material (Fig. 2). If the total of a nonbiogenic component is $>60 \%$, the main name is determined by the relative proportions of sand, silt, and clay when plotted on a modified Shepard's diagram (1954). Under this classification scheme, biogenic components are not described in textural terms. Genetic terms, such as pelagic, hemipelagic, turbiditic, and debris flow, do not appear within this classification. The term "clay" is used for both clay minerals and other siliciclastic material $<4 \mu \mathrm{m}$ in size.

Lithologically similar sediments were grouped into stratigraphic units. Subunits were defined within units by grouping sediments with common accessory components. A legend of the symbols used to represent the different lithologies and contact types in stratigraphic sections is shown in Figure 3. Figures 4 and 5 show the regional stratigraphic correlation (Figs. 4A, 5A) and variations in the calcium carbonate content of lithologic units (Figs. 4B, 5B) between each site.

\section{RESULTS AND DISCUSSION}

The locations of the drill sites occupied during Leg 175 are shown in Figure 1. Each of the regions is described below.

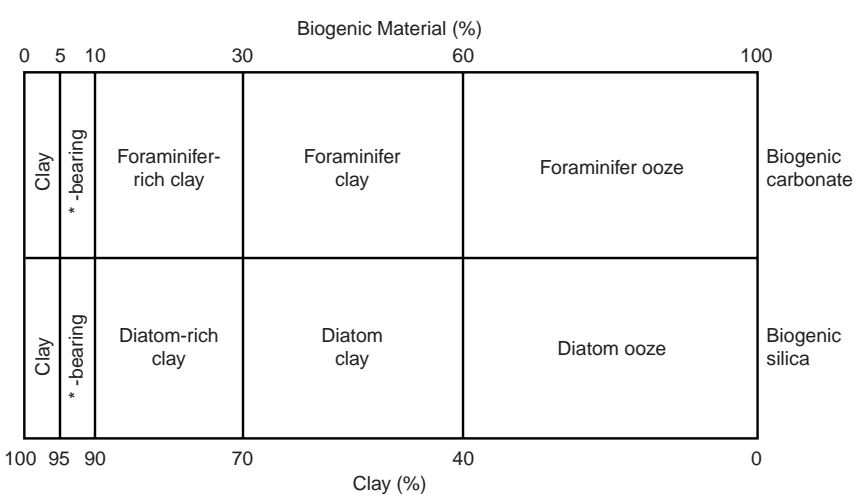

Figure 2: Classification scheme and the naming procedure for mixtures of siliciclastic and biogenic sediments. The names for microfossil components and the siliciclastic fraction are examples only (i.e., placeholders) and can be replaced by any valid textural name (for siliciclastic fraction) or microfossil name. Examples are foraminifer silty clay and nannofossil-rich sandy mud. The asterisks in the scheme for biogenic-clastic mixtures indicate an unusual component, such as plant debris, which is present in amounts of 5\%-10\%.

\section{Lower Congo Basin (Sites 1075-1077)}

Sediments within the Lower Congo Basin form one lithostratigraphic unit, I, which spans the Holocene to Pliocene (Figs. 4-6). Unit I is composed of moderately bioturbated, greenish gray and olive-gray glauconite-rich clay, diatomaceous clay, and nannofossilrich clay with rare silicoflagellates, sponge spicules, phytoliths, and radiolarians. Authigenic components include silt-sized dolomite rhombs, grains of framboidal pyrite, and abundant fine sand-sized peloids of glauconite. Unit I can be correlated among Sites 1075, 1076 , and 1077. It becomes increasingly more diatom and nannofossil rich and less glauconitic toward Site 1075, away from the siliciclastic plume of the Congo River and closer to the center of the highly productive Angola upwelling dome (Fig. 7).

Sedimentation within the Lower Congo Basin is dominated by rain-out of suspended clay derived from the Congo River to the southeast and by pelagic settling of biogenic debris. Unlike other riverinfluenced hemipelagic systems, the Lower Congo Basin sediments lack a significant river-borne sand and silt fraction. Jansen et al. (1984) have shown that the Congo River drops much of its coarse load before reaching the open ocean. The sediment is trapped within the river-canyon system, essentially starving the shelf of coarse detritus (Jansen et al., 1984; van der Gaast and Jansen, 1984). Windderived silt is minimal in relation to the amount of river-deposited clay and thus does not constitute a major component within the sediment (see "Lithostratigraphy" sections, "Site 1075," "Site 1076," and "Site 1077" chapters, this volume; also see Jansen et al., 1996).

Sedimentological evidence suggests that turbidity currents played a minimal role in transporting and redistributing sediment at Sites 1075, 1076, and 1077. The only evidence for such currents comes from a $3-\mathrm{cm}$-thick package of laminated clays interpreted as a thin package of DE turbidites at Site 1076. DE turbidites consist of parallellaminated silt and mud (division D) overlain by hemipelagic mud (division E; Walker, 1984). Laminae are 2-3 mm thick and have broken pteropod shells at their bases. The package at Site 1076 has sharp lower and upper contacts and is coincident with a paraconformity at $\sim 120$ mbsf (see "Biostratigraphy and Sedimentation Rates" section, "Site 1076" chapter, this volume).

\section{Angola Basin (Sites 1078-1080)}

Sediments within this hemipelagic environment form one lithostratigraphic unit, I, which spans the Holocene to early Pleistocene 


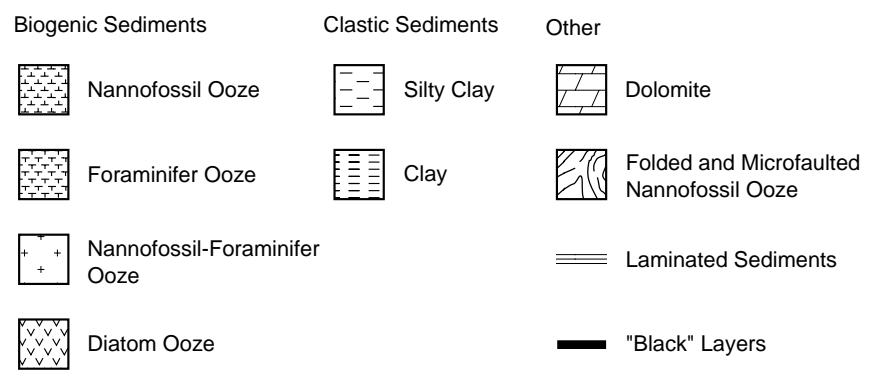

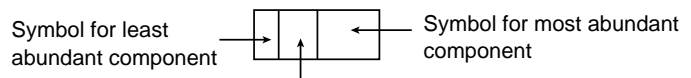

Symbol for component of intermediate abundance

$\longrightarrow$ sharp $\quad$ Contacts

Figure 3. Legend for ornaments used to represent lithology and for contact types in stratigraphic sections.

(Figs. 4, 5, 8). It is composed of 40- to 150-cm-thick intercalated layers of moderately bioturbated olive-gray, dark olive-gray, glauconiterich, silty clay. Contacts between layers are gradational over $20-30$ $\mathrm{cm}$. The silt fraction is composed of subangular and angular monoand polycrystalline quartz grains with subordinate amounts of feldspar. Muscovite, biotite, and detrital apatite are present in trace amounts. The biogenic component is dominated by frequent foraminifer fragments and nannofossils. Three packages of laminated sediments are present within drill cores at Site 1078 (Figs. 4, 8). The packages are 40,26 , and $40 \mathrm{~cm}$ thick, are diatom-rich, and have sharp upper and lower contacts. Dolomitized clay horizons $3-10 \mathrm{~cm}$ thick are also present within drill cores from Sites 1078 and 1080.

Unit I is correlative among Sites 1078, 1079, and 1080. At Site 1080 , biostratigraphic evidence indicates that the upper $10 \mathrm{~m}$ of the sedimentary succession either has a very low sedimentation rate, or it is incomplete, punctuated by numerous hiatuses (see "Biostratigraphy and Sedimentation Rates" section, "Site 1080" chapter, this volume). Dolomitic horizons do not appear to be correlative between drill cores from Sites 1078 and 1080. However, their apparent discontinuity may be an artifact of poor recovery in some drill cores.

As in the Lower Congo Basin, the sediments here are glauconite rich, and deposition is dominated by hemipelagic rain-out of silts, clays, and biogenic debris. Major differences are the greater abundance of silt-sized grains and the presence of laminated packages and dolomite horizons. At Site 1079, the presence of a 60-cm-thick turbidite at $96.5 \mathrm{mbsf}$ indicates that turbidity currents were important in moving sediment to more distal positions on the shelf within the past $250 \mathrm{ka}$. X-ray diffraction (XRD) analyses of the sediment suggests that the silt fraction may be derived from igneous complexes in southern Africa. It may be transported from the Kunene River northward by the Benguela Current, or derived from erosion and offshore transport of silt from neritic depositional settings, or from eolian dust, or a combination of the two (see "Lithostratigraphy" section, "Site 1079 " chapter, this volume.)

\section{Walvis Ridge and Basin (Sites 1081-1084)}

The sediments from Sites 1081, 1082 and 1083 form two lithostratigraphic units, I and II, which together span the Holocene to late Miocene (Figs. 4, 5, 9). Unit I can be subdivided into three subunits, IA, I, and IC, based on changing diatom abundance within the sediment. Subunit IA is composed of 60- to 250-cm-thick intercalated intervals of moderately bioturbated olive to olive-gray nannofossil clay and nannofossil, foraminifer-rich clay. Contacts between intervals are gradational over $20-30 \mathrm{~cm}$. Sediment in Subunit I consists of 60to $250-\mathrm{cm}$-thick moderately bioturbated, intercalated intervals of black and dark olive-gray diatom-rich clay. As in Subunit IA, contacts between intervals are gradational over 20 to $30 \mathrm{~cm}$. Subunit IC consists of olive to olive-gray nannofossil-rich clay. Contacts between subunits are gradational and occur over tens of meters. Unit II consists of moderately bioturbated intervals of olive-gray, pale olive clayey nannofossil ooze. The contact between Units I and II is gradational over a span of $10 \mathrm{~m}$.

Sediments from Site 1084 form four lithostratigraphic units, I-IV, which together span the Holocene to late Miocene (Figs. 4, 5, 9). Unit I is composed of olive, olive-gray, dark olive-gray, and black clays, which contain varying abundances of diatoms, nannofossils, foraminifers, and radiolarians. Three subunits, IA, IB, and IC, are recognized based on microfossil type and abundance. Subunit IA is composed of moderately bioturbated foraminifer- and diatom-bearing nannofossil clay and foraminifer-bearing diatom-rich clayey nannofossil ooze. Subunit IB consists of alternating intervals of nannofossil-rich diatomaceous clay, nannofossil ooze, and diatom-bearing clay. Intervals range in thickness from 3.5 to $8 \mathrm{~m}$. Subunit IC contains moderately bioturbated, nannofossil-rich diatomaceous clay. Contacts between subunits are gradational.

Unit II is composed of clay- and nannofossil-rich diatom ooze, which grades into diatomaceous nannofossil ooze and clay-rich nannofossil ooze. Unit III contains moderately bioturbated diatom-bearing nannofossil clay with 50- to 100 -cm-thick intercalations of clay and nannofossil-rich clay. Unit IV consists of moderately bioturbated clayey nannofossil ooze, diatom-bearing clayey nannofossil ooze, and diatom-rich clayey nannofossil ooze. Contacts between units are gradational over tens of meters.

The stratigraphies of sediments from Sites 1081, 1082, and 1083 are correlative with those from Site 1084 and can be arranged into informal stratigraphic Members 1-4 (Fig. 9). Member 1 consists of Subunit IA from Sites 1081, 1082, and 1083 and Subunit IA from Site 1084. It thins and thickens from a minimum of $77 \mathrm{~m}$ at Site 1081 to a maximum of $133 \mathrm{~m}$ at Site 1083 and becomes more nannofossil rich and less clay rich toward Site 1084. Member 2 is diatomaceous and is composed of Subunit IB from Sites 1081, 1082, and 1083 and Subunits IB and IC and Unit II from Site 1084. It becomes progressively more diatom-rich and less clay rich toward Site 1084. Member 2 thickens from $160 \mathrm{~m}$ at Site 1081 to $391 \mathrm{~m}$ at Site 1084 . Member 3 is composed of Subunit IC from Sites 1081 and 1082 and Unit III from Site 1084. This member thins from $62 \mathrm{~m}$ at Site 1081 to $49 \mathrm{~m}$ at Site 1084. It becomes more nannofossil rich and less clay rich toward the center of upwelling at Site 1084. Member 4 is formed by Subunit IC from Sites 1081 and 1082 and by Unit IV from Site 1084. It progressively becomes more nannofossil rich toward the south. Inferences regarding changes in thickness of this member cannot be made because its base was not intersected.

Member 1 spans the Holocene to Pleistocene at Sites 1081, 1082, and 1084 (Fig 5). Where it thickens at Site 1083 (Fig. 9), sediments composing this member have Holocene to late Pliocene ages (Fig. 5). Member 2 spans the Pleistocene to early Pliocene. Sediments forming Member 3 have early Pliocene to late Miocene ages at Site 1081 and late Pliocene to early Pliocene ages at Site 1084. Late Miocene sediments compose Member 4 at Site 1081, whereas early Plioceneto late Miocene-aged sediments form this member at Site 1084.

Smear-slide analysis indicates that the detrital component of the sediment at all sites is a clay with rare, silt-sized, angular and subangular, mono- and polycrystalline quartz grains, albite, and microcline. Muscovite and biotite are present in trace amounts. XRD analysis of sediment from Sites 1081 and 1082 reveals that the clay fraction is dominated by smectite, kaolinite, and illite. The clastic fraction dominates Member 1, whereas biogenic carbonates become the most abundant component in Members 2-4. Authigenic minerals include trace abundances of glauconite and framboidal pyrite. Siltsized dolomite rhombs are also present throughout the sediment. The biogenic component consists of varying abundances of foraminifers (both whole and fragments), nannofossils, diatoms, radiolarians, sponge spicules, and silicoflagellates. 


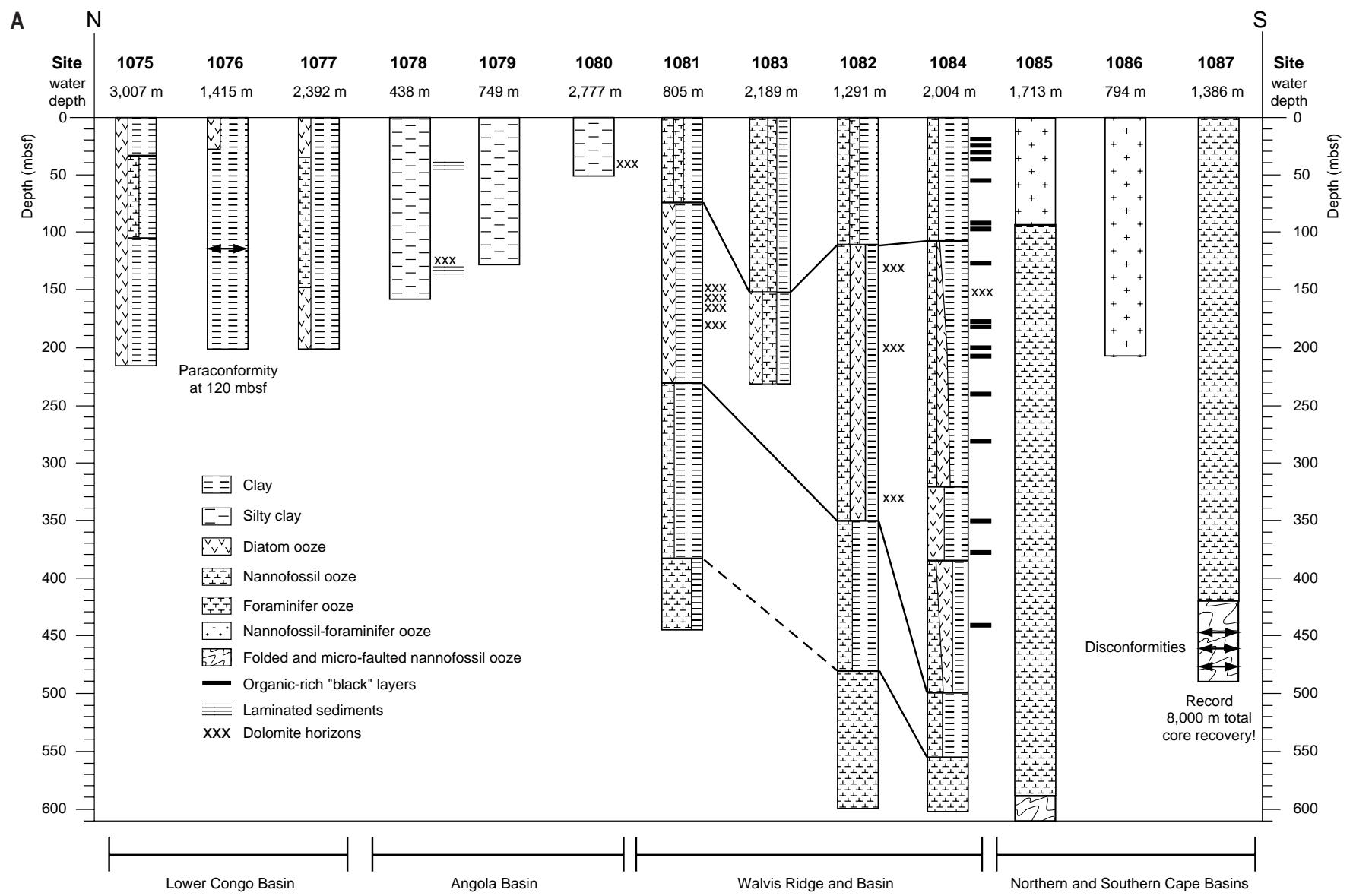

Figure 4. Simplified regional fence diagrams. A. The stratigraphic correlation of sediments recovered during ODP Leg 175. (Continued on next page.)

Dolomitic horizons are present in drill cores within Member 2 in Subunit I at Sites 1081, 1082, and 1083 and in Subunit I at Site 1084. The Formation MicroScanner used during downhole logging of Sites 1081, 1082, and 1084 detected additional dolomitic layers within Subunit IC and Unit II at Sites 1081 and 1082 and within Units II and IV at Site 1084 (see "Downhole Logging" section in "Site 1081," "Site 1082," and "Site 1084" chapters, this volume). No dolomite horizons were identified above 100 mbsf because the upper 60-100 $\mathrm{m}$ of the drill holes were not logged.

Site 1084 also contains unique, organic-rich intervals that were not present at any other site. These dark olive-brown and black intervals, or "black" layers (Figs. 4, 9), are variable in composition (Table 1) and generally range in thickness from 30 to $150 \mathrm{~cm}$ to a maximum of $9 \mathrm{~m}$. "Black" layers have very high organic carbon and low carbonate contents compared with sediments above and below. They are most common within Member 1 in Subunits IA and I at Site 1084 (Table 1). In Subunit IA, "black" layers are characterized by low calcium carbonate contents, which average just below $10 \mathrm{wt} \%$, and high organic carbon contents ranging between 8 and $18 \mathrm{wt} \%$. The second highest ODP or DSDP pore-water alkalinities ever recorded were found at this site (see "Inorganic Geochemistry" section, chap. 12; Murray et al., chap. 20; both this volume). "Black" layers are thought to record periods of high productivity associated with intense upwelling, or periods of excellent preservation, or (most probably) both.

In summary, three major stratigraphic trends are recognized at the Walvis Ridge and Basin: (1) the relative abundance of diatoms increases from north to south until diatomaceous sediments dominate in the Walvis Basin; (2) the organic carbon content of the sediments and the frequency of organic-rich, dark olive-brown and black layers increases southward toward the upwelling center in the Benguela Current region; and (3) the dolomitic horizons are common within the sediments.

\section{Cape Basin (Sites 1085-1087)}

Sediments from the Cape Basin are distinct from those from other Leg 175 sites because they consist predominantly of foraminifer-nannofossil ooze and nannofossil ooze. These sediments form two lithostratigraphic units, I and II, that span the Holocene to middle Miocene (Figs. 4, 5, 10). At Site 1085, Unit I is subdivided into Subunits IA and I to reflect a decrease in the foraminiferal abundance with depth. Sediments forming Subunit IA range in age from Holocene to late Pliocene (Fig. 5) and are composed of moderately bioturbated, intercalated intervals of olive, clay-rich nannofossil-foraminifer ooze, and pale olive, light olive-gray, dark greenish gray nannofossil-foraminifer ooze. Intervals range in thickness from 80 to $200 \mathrm{~cm}$ and grade into one another over $15-20 \mathrm{~cm}$. Two- to $17-\mathrm{cm}$-thick graded beds rich in foraminifer tests are common within the upper $100 \mathrm{~m}$ of Subunit IA at Site 1085. The thickest beds have sharp, erosive bases and have foraminifer tests concentrated within the lower few centimeters. Subunit I spans the late Pliocene to middle Miocene (Fig. 5) and consists of moderately bioturbated intervals of greenish gray, light greenish gray, light gray, and pale olive nannofossil ooze. The contact between Subunits IA and I is gradational over several meters.

At Sites 1086 and 1087, the subdivision of Unit I is not possible. It is composed of moderately bioturbated clay-rich foraminifer-nannofossil ooze, foraminifer-rich nannofossil ooze, and nannofossil ooze. At Site 1086, egg-shaped carbonate concretions 3 to $5 \mathrm{~cm}$ thick are present in Unit I at 145 and 172 mbsf. Unit I thins from 594 mbsf 


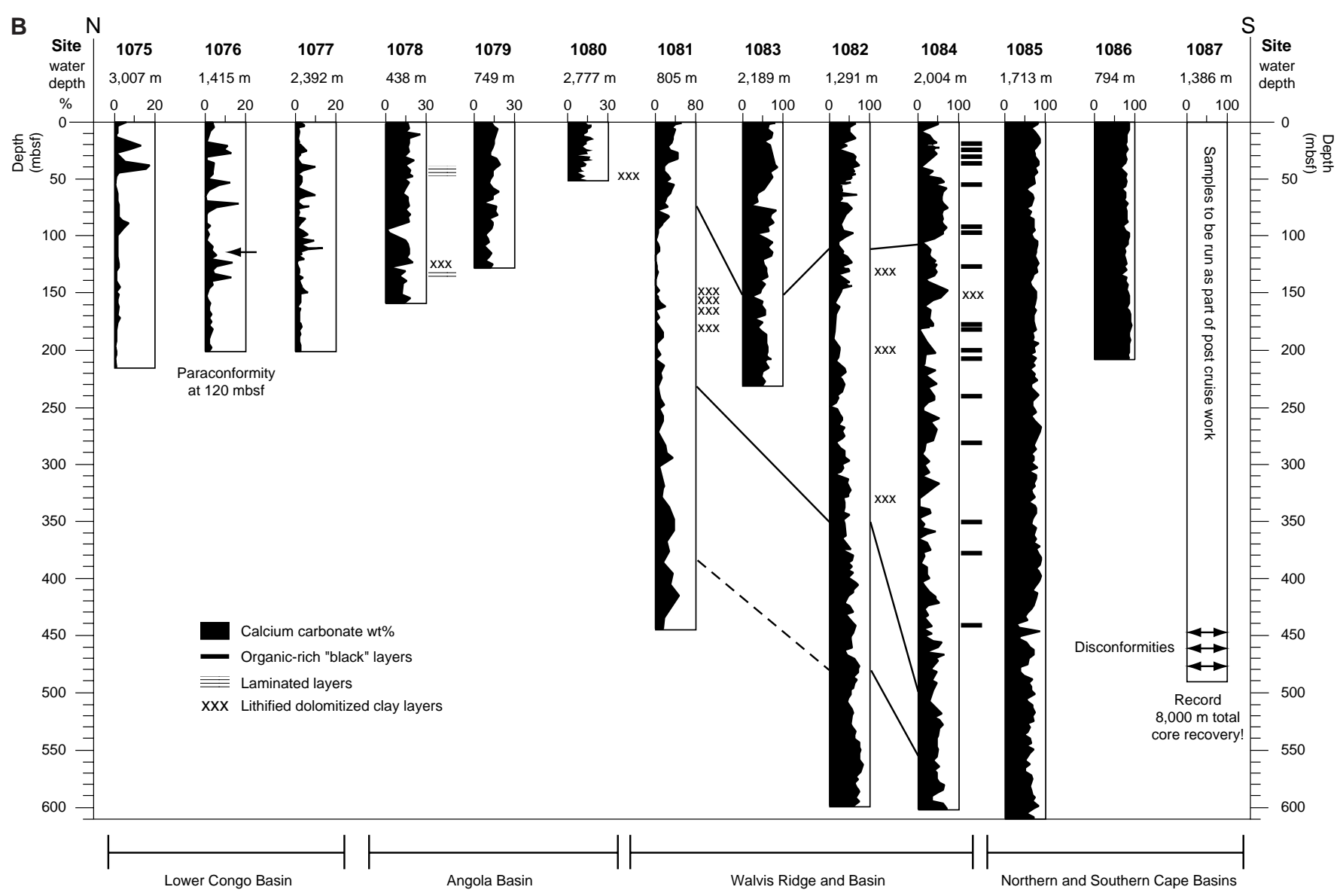

Figure 4 (continued). B. The downhole variation in calcium carbonate content of sediments recovered during ODP Leg 175.

at Site 1085 to 425 mbsf at Site 1087. Its contact with Unit II is sharp where it was intersected (Sites 1085 and 1087). Unit I spans the early Pleistocene to late Miocene at Site 1086 and the early Pleistocene to early Oligocene at Site 1087 (Fig. 5).

Unit II is composed entirely of thinly laminated, microfaulted, convolutely layered light gray nannofossil ooze and gray clay-rich nannofossil ooze. Laminae have sharp bases and range in thickness from 2 to $4 \mathrm{~mm}$; some are graded. At Site 1085, only $9.6 \mathrm{~m}$ of Unit II was recovered; it was deposited at the end of the middle Miocene. At Site 1087, $56 \mathrm{~m}$ of Unit II were recovered, covering the interval from the middle Miocene to early Oligocene. Three disconformities were identified within this unit at 424, 444, and 452 mbsf. They record stratigraphic breaks between the late middle Miocene and the middle Miocene, the middle Miocene and the early Miocene, and the early Miocene and the late Oligocene (see "Biostratigraphy and Sedimentation Rates" section, "Site 1087" chapter, this volume). In the cores, these disconformities are marked by pyrite nodules with iron oxiderich rims. The largest nodule is $10 \mathrm{~cm}$ in diameter and occurs at $\sim 455$ mbsf at Site 1087.

Unit II is interpreted as a series of slump blocks emplaced in the middle Miocene during a period of prolonged slope instability. These slump blocks may have been generated by erosion of the upper slope associated with changes in ocean circulation that occurred between the late Oligocene and middle Miocene (Kennett et al., 1985; Haq et al., 1987). Strong, shelf-parallel currents capable of eroding the upper slope may have developed in response to increased production of intermediate waters in the Southern Ocean and South Atlantic during the late Oligocene to middle Miocene.

Smear-slide analysis indicates that the detrital component of the sediments is dominated by clay in trace to frequent abundance and trace amounts of silt-sized, subangular mono- and polycrystalline quartz grains. When present, pyrite is found in trace amounts as siltsized aggregates or as framboids. Rounded, coarse silt-sized, honeybrown apatite grains are present in 1- to 3-mm-thick laminae in the upper $90 \mathrm{~m}$ of Unit I at Site 1086, within discrete, 20- to 30-cm-thick packages of yellowish brown nannofossil ooze in Subunit I at Site 1085, and at all three sites as individual, disseminated grains. Apatite-rich laminae have sharp upper and lower contacts and are commonly disrupted by bioturbation. The discrete, yellowish brown packages of nannofossil ooze frequently contain rounded apatite grains. Packages range in thickness from 20 to $30 \mathrm{~cm}$ and are spaced at regular intervals of 50-60 cm. Their upper and lower contacts are gradational over $10-15 \mathrm{~cm}$ with the enveloping sediment. Similar reddish colored packages are also present at Site 1085. Smear-slide analysis reveals that packages have reddish brown, subhedral to anhedral, silt-sized crystals disseminated throughout. Grains have high relief and are interpreted as being either titanite or rutile. Like the apatite-rich packages, the reddish brown packages are spaced at regular intervals of $50-60 \mathrm{~cm}$.

Sedimentation within the Cape Basin is dominated by pelagic settling of biogenic debris at the southernmost tip of the Benguela Current upwelling center. Since the middle Miocene, the deposition has been continuous with no major breaks in stratigraphy. Common graded beds with sharp erosive bases rich in foraminifer tests and graded laminae of nannofossil ooze in Unit II indicate that turbidity currents have played an important role in redistributing sediment within the Cape Basin. The apatite-rich laminae at Site 1086 may have formed from winnowing apatite-bearing nannofossil oozes into discrete, apatiterich laminae by slope parallel currents. The regularly spaced packages of apatite and titanite/rutile-rich sediment may record changes in the 


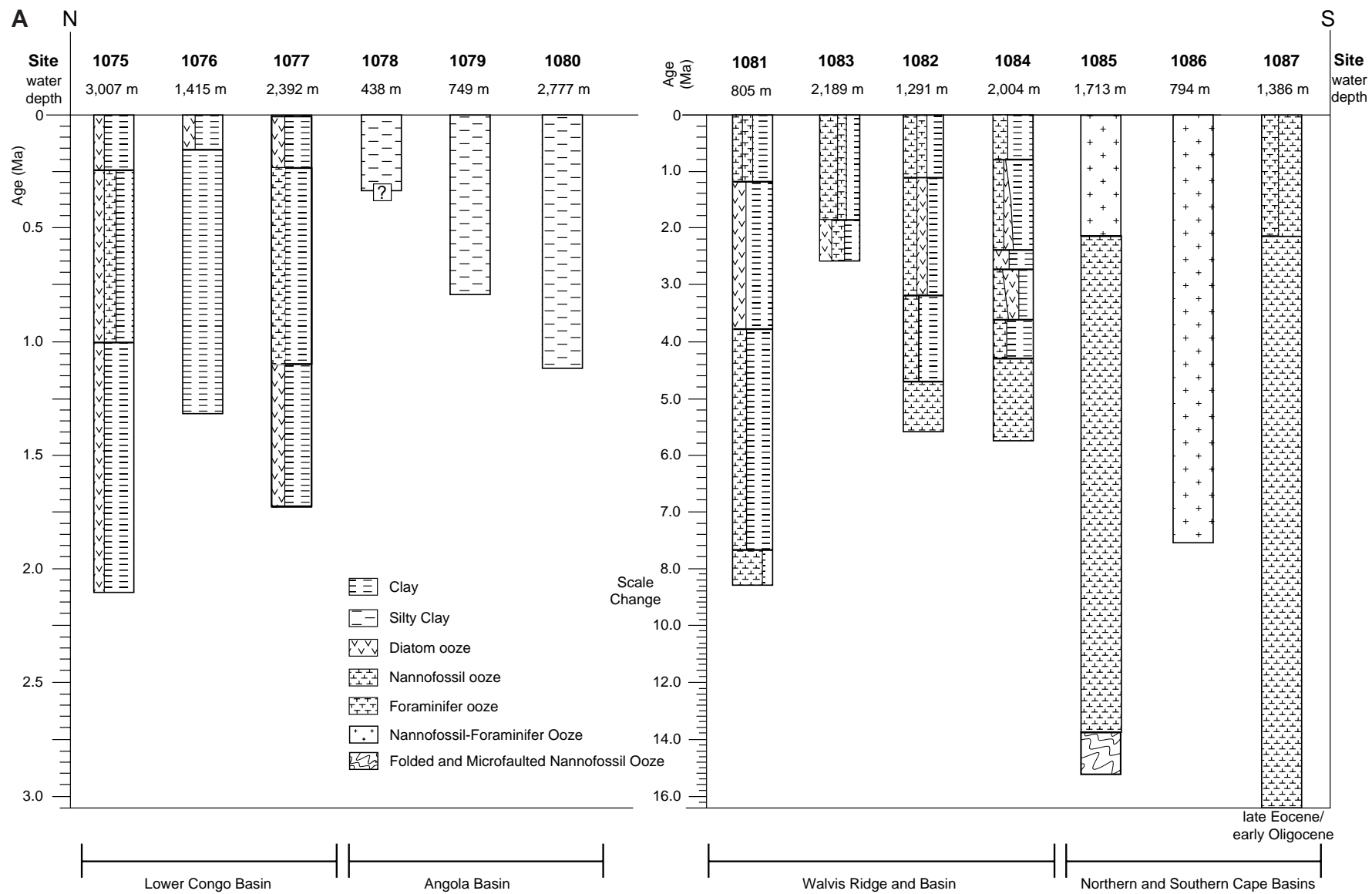

Figure 5. Lithostratigraphic summary diagrams. A. The relative ages (y-axis) of stratigraphic units of sediments recovered from the Lower Congo Basin, Angola Basin, Walvis Ridge and Basin, and the Northern and Southern Cape Basins. (Continued on next page.)

intensity of offshore-directed currents through time, which transported apatite and titanite/rutile from near-shore environments.

\section{CONCLUSIONS}

Each of the four regions investigated during Leg 175 records distinct sedimentological and paleoceanographic regimes. The Congo Basin is a river-influenced hemipelagic environment, the Angola Basin is dominated by hemipelagic sedimentation, the Walvis Ridge and Basin record hemipelagic sedimentation with a strong upwelling signal, and the Cape Basin contains pelagic sediment that has a significant portion of shelf-derived sediment that predates the middle Miocene. Although much has been learned from studying the sediments along the southwest African margin during Leg 175, the following questions remain unanswered:

1. What is the stratigraphic significance of glauconite in the Lower Congo and Angola Basins? Glauconites have long been regarded as one of the best indicators of low sedimentation rates in marine settings (Odin and Matter, 1981; Amorosi, 1995). However, sedimentation rates within these regions range between 10 and $30 \mathrm{~cm} / \mathrm{k} . \mathrm{y}$., which is higher than those at the Walvis Ridge and Cape Basin (see Giraudeau et al., Chap. 19, this volume).

2. How do the dolomites from the Angola Basin, Walvis Ridge, and Walvis Basin compare with other dolomites recovered during DSDP Leg 64 (Guaymas Basin; Curray, Moore, et al.,
1982) and ODP Leg 112 (Peruvian margin; Suess, von Huene, et al., 1988)?

3. What is the stratigraphic and paleoceanographic significance of the laminated sediments in the Angola Basin?

4. What climatic signals do the "black" layers from the Walvis Ridge and Basin record?

5. Do the disconformities at Site 1087 represent major changes in paleoceanography?

Future work will address these questions by integrating the descriptive sedimentology and stratigraphy outlined in this report with geochemical, paleontological, and geophysical data acquired on board and by developing high-resolution stratigraphies to obtain a more detailed picture of the Benguela Current region since the middle Miocene.

\section{REFERENCES}

Amorosi, A., 1995. Glaucony and sequence stratigraphy: a conceptual framework of distribution in siliciclastic sequences. J. Sediment. Res., B65:419-425.

Curray, J.R., Moore, D.G., et al., 1982. Init. Repts. DSDP, 64 (Pts. 1 and 2): Washington (U.S. Govt. Printing Office).

Haq, B.U., Hardenbol, J., and Vail, P.R., 1987. Chronology of fluctuating sea levels since the Triassic. Science, 235:1156-1167.

Jansen, J.H.F., Ufkes, E., and Schneider, R.R., 1996. Late Quaternary movements of the Angola-Benguela-Front, SE Atlantic, and implications for advection in the equatorial ocean. In Wefer, G., Berger, W.H., Siedler, G., and Webb, D. (Eds.), The South Atlantic: Present and Past Circulation: Berlin (Springer-Verlag), 553-575. 
Jansen, J.H.F., van Weering, T.G.E., Gieles, R., and van Iperen, J., 1984. Middle and late Quaternary oceanography and climatology of the ZaireCongo fan and the adjacent eastern Angola Basin. Neth. J. Sea Res., 17:201-241.

Kennett, J.P., Keller, G., and Srinivasan, M.S., 1985. Miocene planktonic foraminiferal biogeography and paleoceanographic development of the Indo-Pacific region. In Kennett, J.P. (Ed.), The Miocene Ocean: Paleoceanography and Biogeography. Mem.-Geol. Soc. Am., 163:197-236.

Odin, G.S., and Matter, A., 1981. Die glauconarium origine. Sedimentology, 28:611-643.

Shepard, F., 1954. Nomenclature based on sand-silt-clay ratios. J. Sediment. Petrol., 24:151-158.
Suess, E., von Huene, R., et al., 1988. Proc. ODP, Init. Repts., 112: College Station, TX (Ocean Drilling Program).

van der Gaast, S.J., and Jansen, J.H.F., 1984. Mineralogy, opal, and manganese of Middle and Late Quaternary sediments of the Zaire (Congo) deep-sea fan: origin and climatic variation. Neth. J. Sea Res., 17:313341.

Walker, R.G., 1984. Turbidites and associated coarse clastic deposits. In Walker, R.G. (Ed.), Facies Models (2nd ed.). Geol. Assoc. Can., Geosci. Reprint Ser., 1:171-188.

\section{Ms 175IR-118}

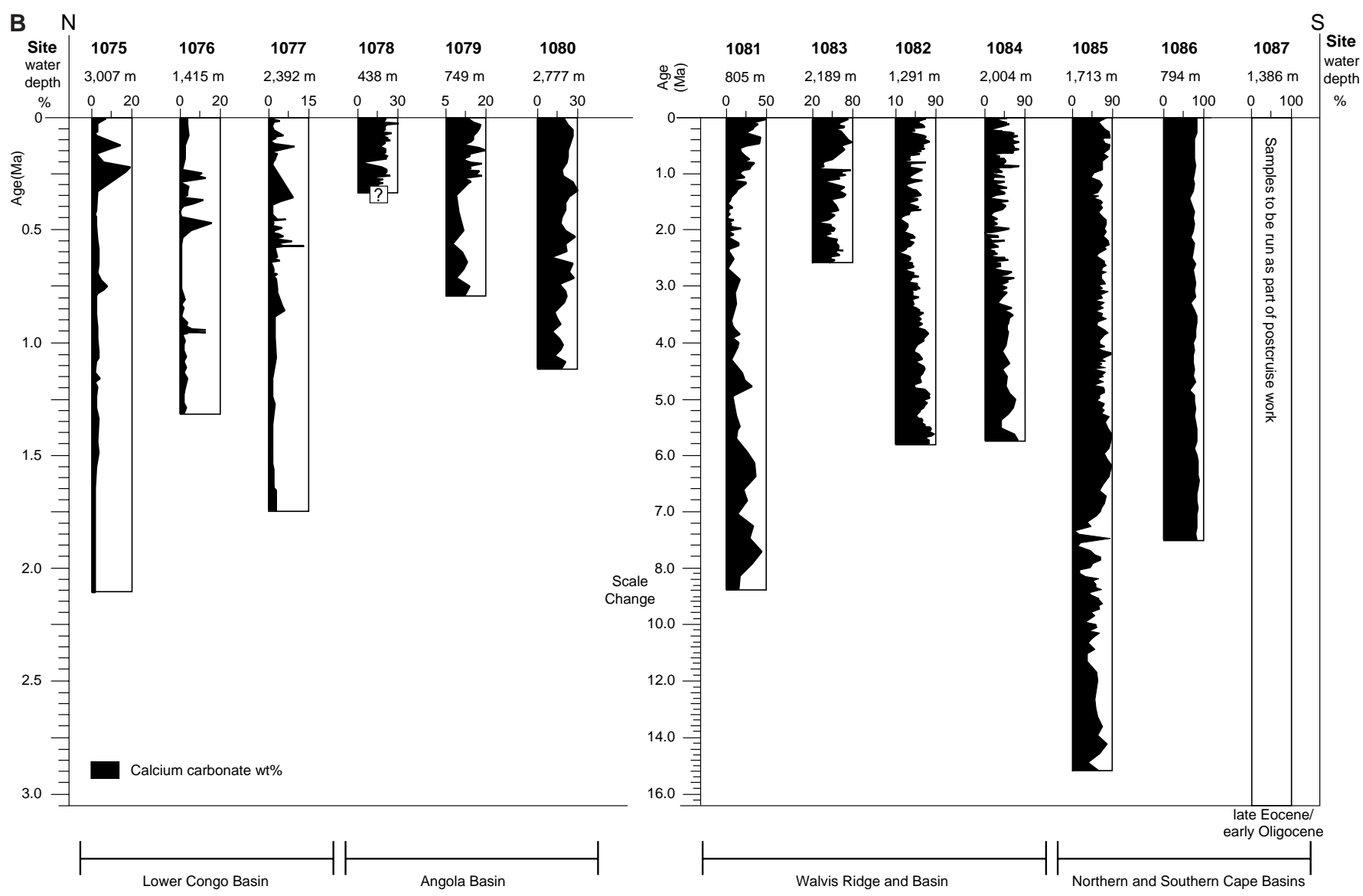

Figure 5 (continued). B. The downhole variation in calcium carbonate content of sediments recovered from the Lower Congo Basin, Angola Basin, Walvis Ridge and Basin, and the Northern and Southern Cape Basins. 
Lower Congo Basin (Sites 1075-1077)

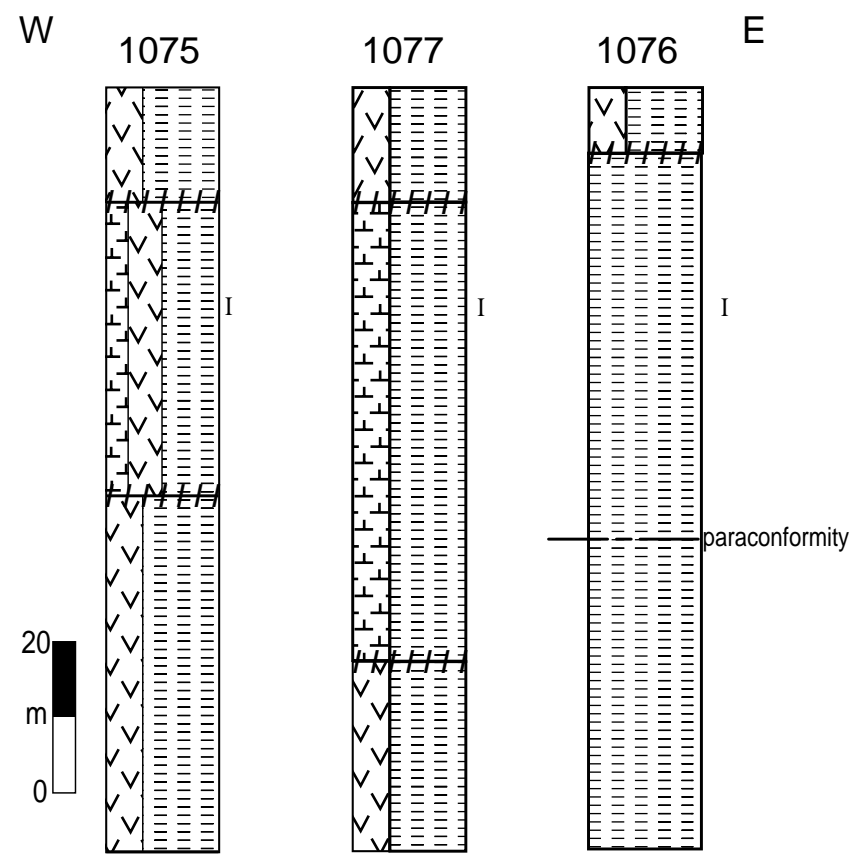

Figure 6. Simplified fence diagram for the Lower Congo Basin sites with the stratigraphic position of the paraconformity at Site 1076.

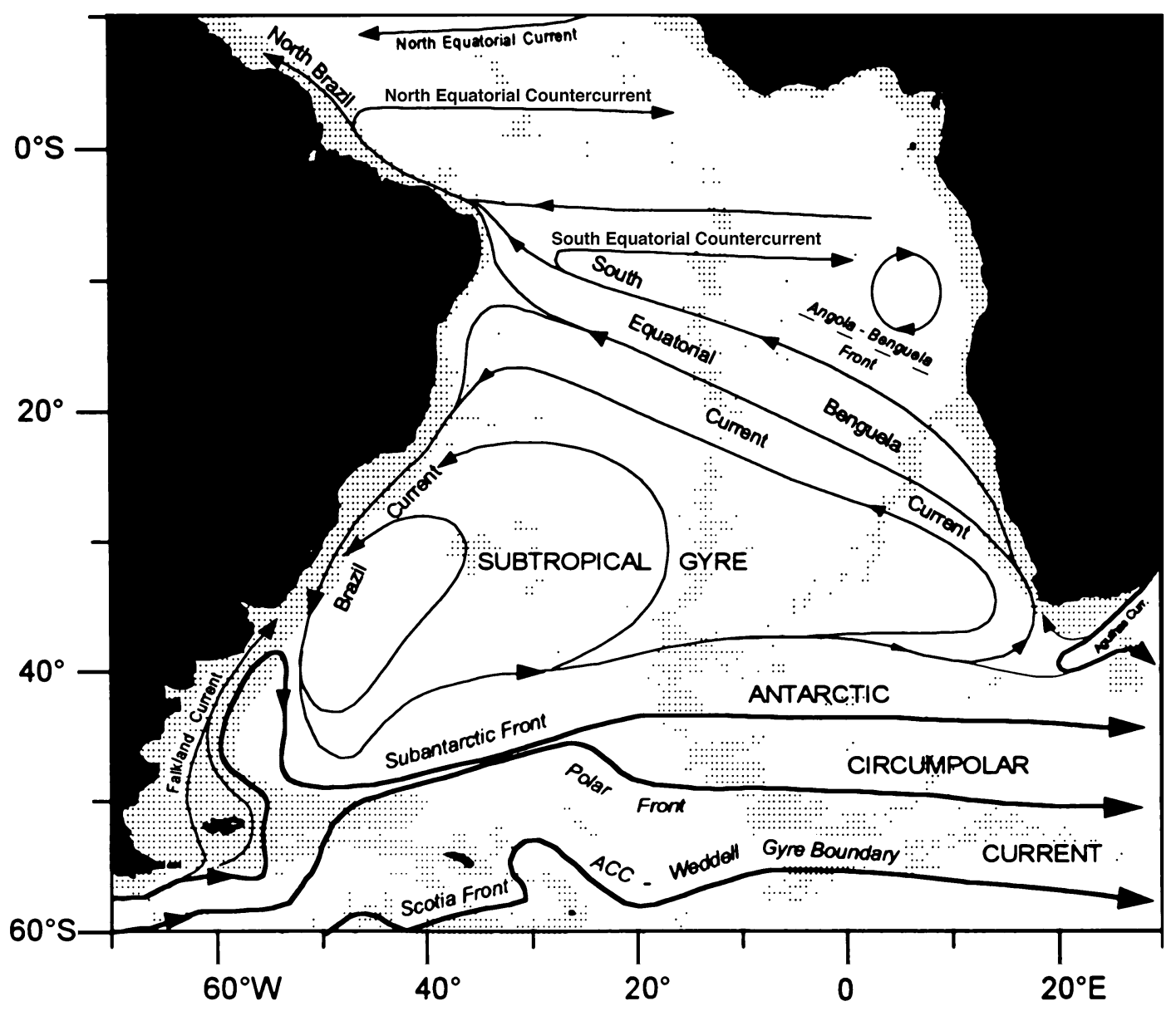

Figure 7. Current regime off southwest Africa. At present, upwelling off southwest Africa occurs on the inner shelf and at the shelf edge (also see "Introduction" chapter, this volume). 
Angola Basin (Sites 1078-1080)

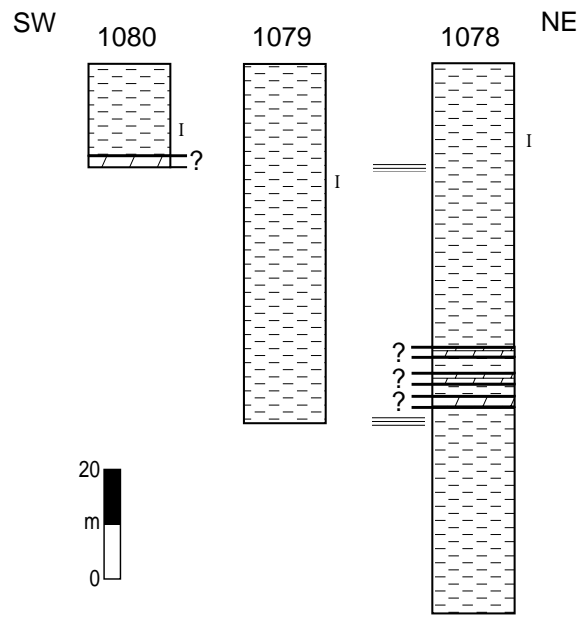

Figure 8. Simplified fence diagram for the Angola Basin sites with stratigraphic positions of dolomite horizons and laminated sediments.

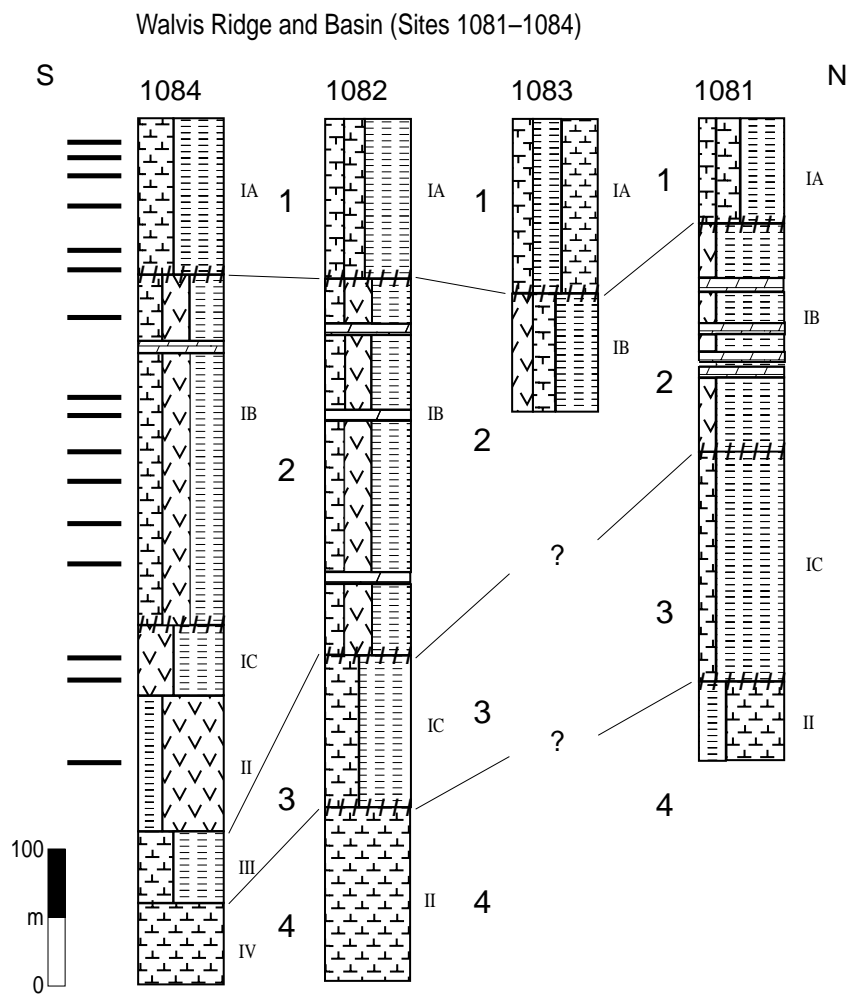

Figure 9. Simplified fence diagram for the Walvis Ridge and Basin sites with stratigraphic positions of dolomite horizons and "black" layers. Arabic numerals refer to Members $1-4$. 
SE

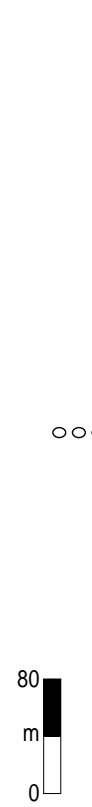

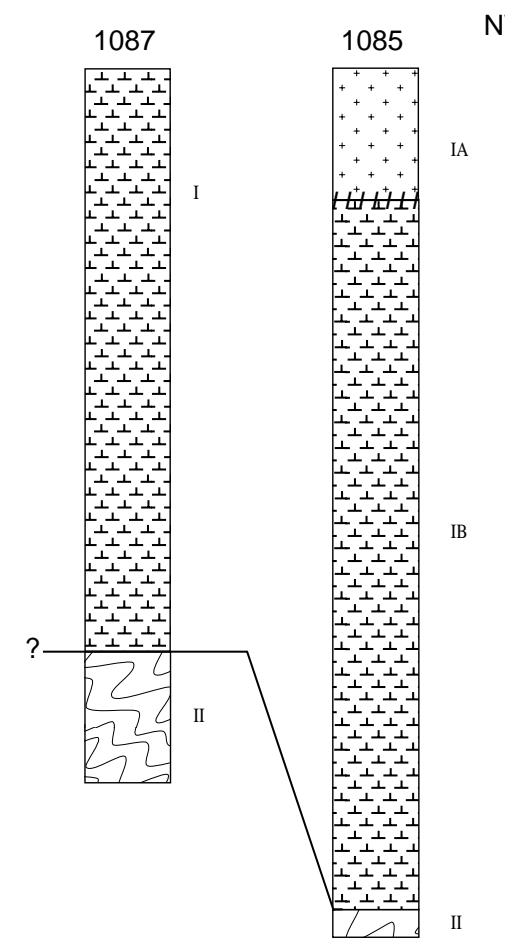

NW

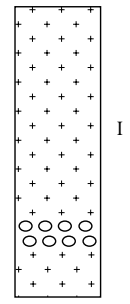

Figure 10. Simplified fence diagram for the Cape Basin sites.

Table 1. Lithologic summary of "black" layers at Hole 1084A.

\begin{tabular}{|c|c|c|c|c|c|c|c|c|c|}
\hline $\begin{array}{l}\text { Core, section, } \\
\text { interval }(\mathrm{cm})\end{array}$ & $\begin{array}{l}\text { Depth } \\
\text { (mbsf) }\end{array}$ & Clay & Pyrite & Diatoms & Foraminifers & Nannofossils & $\begin{array}{c}\text { Organic } \\
\text { debris }\end{array}$ & Sediment name & $\begin{array}{c}\text { Lithostratigraphic } \\
\text { units }\end{array}$ \\
\hline \multicolumn{10}{|l|}{ 175-1084A- } \\
\hline $4 \mathrm{H}-1,50$ & 22.5 & A & $\mathrm{R}$ & $\mathrm{F}$ & $\mathrm{R}$ & $\mathrm{C}$ & $\mathrm{R}$ & Diatom-bearing, nannofossil-rich clay & Subunit IA \\
\hline $5 \mathrm{H}-1,100$ & 32.5 & A & $\mathrm{F}$ & C & $\mathrm{T}$ & $\mathrm{T}$ & A & Organic-rich clay & Subunit IA \\
\hline $5 \mathrm{H}-6,80$ & 39.7 & A & $\mathrm{F}$ & $\mathrm{C}$ & B & $\mathrm{B}$ & A & Organic-rich clay & Subunit IA \\
\hline $7 \mathrm{H}-4,120$ & 55.73 & A & $\mathrm{R}$ & $\mathrm{F}$ & $\mathrm{R}$ & $\mathrm{C}$ & $\mathrm{F}$ & Diatom-bearing, nannofossil-rich clay & Subunit IA \\
\hline $11 \mathrm{H}-6,80$ & 95.47 & $\mathrm{~F}$ & B & $\mathrm{C}$ & $\mathrm{F}$ & A & B & Diatom-rich nannofossil ooze & Subunit IA \\
\hline $12 \mathrm{H}-2,80$ & 99.06 & A & $\mathrm{R}$ & $\mathrm{R}$ & B & $\mathrm{C}$ & $\mathrm{C}$ & Nannofossil clay & Subunit IA \\
\hline $14 \mathrm{H}-6,144$ & 126 & A & $\mathrm{F}$ & A & B & B & B & Diatom-rich clay & Subunit IB \\
\hline $21 \mathrm{X}-6,40$ & 179.7 & A & $\mathrm{R}$ & $\mathrm{F}-\mathrm{C}$ & B & A & $\mathrm{R}$ & Foraminifer-bearing nannofossil clay & Subunit IB \\
\hline $22 \mathrm{X}-1,40$ & 181.9 & A & $\mathrm{R}$ & C & $\mathrm{T}$ & $\mathrm{F}-\mathrm{C}$ & $\mathrm{R}$ & Diatom-rich clay & Subunit IB \\
\hline $24 X-5,40$ & 206.1 & A & $\mathrm{T}$ & $\mathrm{C}$ & R-F & $\mathrm{C}$ & $\mathrm{R}$ & Clay & Subunit IB \\
\hline $29 X-2,80$ & 251.2 & A & $\mathrm{T}$ & $\mathrm{F}$ & B & B & $\mathrm{C}$ & Diatom-bearing clay & Subunit IB \\
\hline $33 X-5,70$ & 294 & A & $\mathrm{R}$ & $\mathrm{C}$ & $\mathrm{R}$ & $\mathrm{C}$ & $\mathrm{F}$ & Diatom-rich nannofossil clay & Subunit IB \\
\hline $43 X-4,113$ & 389.3 & A & $\mathrm{T}$ & A & B & $\mathrm{T}$ & $\mathrm{R}$ & Diatomaceous clay & Subunit IC \\
\hline $46 \mathrm{X}-3,15$ & 414.8 & $\mathrm{C}$ & $\mathrm{F}$ & $\mathrm{D}$ & B & $\mathrm{F}$ & $\mathrm{R}$ & Nannofossil-bearing clayey diatom ooze & Unit II \\
\hline $51 X-4,100$ & 466.3 & A & $\mathrm{R}$ & $\mathrm{F}$ & B & $\mathrm{R}$ & $\mathrm{T}$ & Diatom-bearing clay & Unit II \\
\hline
\end{tabular}

Notes: $\mathrm{D}=$ dominant $(>60 \%) ; \mathrm{A}=$ abundant $(30 \%-60 \%) ; \mathrm{C}=$ common $(10 \%-30 \%) ; \mathrm{F}=$ few $(5 \%-10 \%) ; \mathrm{R}=\operatorname{rare}(1 \%-5 \%) ; \mathrm{T}=\operatorname{trace}(<1 \%) ;$ and $\mathrm{B}=$ barren 